\title{
PENENTUAN CSF PADA WEBSITE INTERNET BANKING DITINJAU DARI ASPEK KEBUTUHAN PENGGUNA SEBAGAI NASABAH INDIVIDUAL DENGAN STUDI KASUS BCA, BANK MANDIRI, DAN BNI
}

\author{
Irvan Ferdiansyah dan Putu Wuri Handayani \\ Fakultas Ilmu Komputer, Universitas Indonesia, Kampus UI Depok, Jawa Barat, 16424, Indonesia \\ E-mail: irvan.ferdiansyah@gmail.com
}

\begin{abstract}
Abstrak
Penelitian ini bertujuan untuk mengidentifikasi faktor-faktor implementasi yang dianggap penting dalam penyediaan fasilitas layanan internet banking (e-banking) pada instansi perbankan di Indonesia. Adapun spesifikasi Critical Success Factors (CSF) pada internet banking yang ditelaah adalah dengan memandang kebutuhan dan kenyamanan bertransaksi pengguna sebagai nasabah individual. Tahapan penelitian meliputi studi literatur untuk mendefinisikan CSF pada internet banking serta evaluasi website studi kasus untuk mendefinisikan instrumen evaluasi website. Kemudian instrumen evaluasi tersebut digunakan dalam menguji CSF yang telah didefinisikan sebelumnya. Penelitian ini diakhiri dengan proses analisis atas data survei uji instrumen evaluasi. Hasil akhir penelitian menyimpulkan dua CSF yaitu kelengkapan layanan-layanan internet banking dan desain antarmuka website.
\end{abstract}

Kata Kunci: e-commerce, critical success factors, internet banking

\begin{abstract}
This research aims to identify factors that are considered important in the implementation of the provision of internet banking services (e-banking) in the banking institutions in Indonesia. The Critical Success Factors specification (CSF) on the internet banking which is examined by looking at the needs and convenience of the user transactions as individual customers. Stages of research include studies in the literature to define CSF evaluation in internet banking website as well as case studies to define the website evaluation instruments. Then the evaluation instruments used in testing the CSF that have been defined previously. The research concludes with the analysis of survey data evaluation test instruments. The final results of two studies concluded that CSF completeness of internet banking services and website interface design.
\end{abstract}

Keywords e-commerce, critical success factors, internet banking

\section{Pendahuluan}

Lembaga keuangan pada saat itu memperkenalkan dan mempromosikan internet banking dengan maksud untuk menyediakan layanan perbankan yang lebih baik dari pelayanan sebelumnya [1]. Tidak lama setelah itu, instansi perbankan di Indonesia pun mulai mengadopsi sistem internet banking dengan tujuan yang sama, serta dengan maksud untuk memperluas jaringan pelayanan nasabah. Internet banking di Indonesia, pertama kali diluncurkan pada tahun 1988 oleh BII (PT Bank Internasional Indonesia, Tbk.) dengan aplikasi yang bernama BII Internet Banking. Kemudian, disusul pada tanggal 20 Maret 2001 oleh BCA (PT Bank Central Asia, Tbk.) dengan aplikasi klikBCA, yang selanjutnya pada 26 April 2001 diikuti oleh Bank Niaga (PT Bank Niaga, Tbk.) dengan aplikasi Niaga Global@ccess. Setelahnya pun instansi perbankan lain yang mampu bersaing mulai berlomba-lomba mengadopsi sistem internet banking sebagai salah satu layanan yang menawarkan daya tarik lebih bagi para nasabahnya. Direktur Consumer dari BII Internet Banking mengatakan bahwa hingga kini tidak lagi jarang ditemui sebuah instansi perbankan yang memfasilitasi layanan internet banking, karena memang tidak dapat dipungkiri bahwa internet banking merupakan inovasi di bidang teknologi informasi yang sangat menguntungkan [2].

Manfaat internet banking bagi pihak bank adalah ekspansi bisnis, meningkatkan loyalitas konsumen, pendapatan dan keunggulan kompetitif, serta dapat membuat model bisnisbaru [3]. Terlepas dari keuntungan yang berdampak bagi instansi perbankan, internet banking juga membawa keuntungan bagi nasabah pengguna layanan tersebut, yakni kemudahan bertransaksi perbankan dengan lebih cepat dan mudah serta 
dapat diakses kapan dan di mana saja, dengan ketentuan memiliki koneksi internet dan perangkat komputer atau seluler yang kompatibel. Beberapa tahun ini, instansi perbankan kecil pun sudah mulai nampak adanya pendekatan terhadap sistem internet banking. Salah satu instansi perbankan yang telah membuktikan peluang dalam memperluas jaringan nasabahnya dengan mengimplementasikan berbagai layanan $e$ banking, seperti internet banking dan mobile banking, adalah Bank Permata (PT. Bank Permata Tbk). Tahun 2005, managing director Bank Permata mengklaim bahwa fasilitas $e$-banking ini telah memberikan kontribusi kepada Bank Permata sebesar Rp 3 miliar per bulan dari revenue keseluruhan sebesar $\mathrm{Rp} 1$ triliun [4].

Namun demikian, kurangnya best practice guidelines yang membahas critical success factors dalam membangun dan mengimplementasikan sebuah sistem internet banking menjadi salah satu faktor penghambat terwujudkan sistem internet banking dengan sempurna di beberapa instansi perbankan. Padahal untuk mengembangkan sistem internet banking ini, pihak bank perlu mengalokasikan dana operasional yang tidak sedikit jumlahnya, sebagai contoh BII sampai mendanakan US \$1 juta untuk mengembangkan sistem internet banking miliknya [2].

Penelitian ini akan membahas faktor-faktor apa saja yang dianggap penting untuk diperhatikan dalam mengimplementasikan layanan internet banking dipandang dari kebutuhan dan kenyamanan bertransaksi pengguna sebagai nasabah individual dengan mengambil studi kasus tiga bank publik terbaik berdasarkan data dari statistik perbankan Indonesia terkait bank umum nasional dengan aset terbesar per Agustus 2009 yang dikutip dari website Bank Indonesia yaitu PT. Bank Mandiri, Tbk. (https://ib.bankmandiri.co.id/), PT. Bank Central Asia, Tbk. (https://ibank.klikbca.com/), PT. Bank Nasional Indonesia, Tbk. (https://ibank.bni.co.id/). Diharapkan pula dengan tersusunnya faktor-faktor ini akan dapat dilakukan penilaian terhadap pemfasilitasan layanan internet banking yang telah ada melalui pendefinisian sebuah instrumen evaluasi website internet banking sehingga memudahkan instansi perbankan dalam melakukan perbaikan pelayanan kepada nasabah pengguna internet banking.

Definisi internet banking menurut Budi Agus Riswandi tahun 2005 adalah penggunaan Internet sebagai alat pengendali untuk jasa bank, termasuk jasa perbankan tradisional seperti membuka rekening deposito atau mentransfer dana antara rekening berbeda, seperti halnya jasajasa terbaru dari bank, seperti penyajian dan pembayaran tagihan elektronik yang memungkinkan pelanggan untuk menerima dan membayar tagihan melalui website bank [5]. Sedangkan, definisi internet banking menurut Efraim Turban adalah berbagai macam kegiatan perbankan yang terhubung dari rumah, bisnis, atau dengan mobilitas dibandingkan sebuah lokasi fisik berupa gedung bank. Dari pengertian ini dapat disimpulkan secara sederhana bahwa internet banking merupakan suatu bentuk pemanfaatan media internet oleh bank untuk mempromosikan dan sekaligus melakukan transaksi secara online, baik dari produk yang sifatnya konvensional maupun yang baru.

Menurut Budi Agus Riswandi (2005) terdapat beberapa tipe layanan perbankan melalui media website, yaitu informational web, transactional web, wireless, dan PC banking [5]. Informational web merupakan layanan tingkat dasar perbankan. Dalam tipe ini, layanan perbankan sudah melalui website, tetapi hanya menampilkan informasi saja. Risiko dari model layanan perbankan seperti ini relatif rendah. Transactional web, pada tingkatan layanan perbankan ini nasabah sudah mulai diberikan kemampuan untuk mengeksekusi transaksi dengan risiko yang cukup tinggi dibanding dengan informational web. Transactional web memungkinkan nasabah untuk melakukan pembelian barang dan jasa serta transaksi perbankan secara online melalui internet banking. Aktivitas perbankan yang dapat nasabah lakukan seperti mengakses rekening, membeli produk dan jasa, mengajukan pinjaman, pembayaran, dan transfer dana. Wireless merupakan teknologi yang mengizinkan bank untuk menawarkan kepada nasabah tradisional mengenai produk dan jasa baru dengan cara pengembangan channel yang lain. Bank menyediakan produk dan jasa nasabah melalui wireless device, seperti telepon selular, pager, dan personal digital assistance yang mempunyai akses wireless pada bank. PC banking tipe layanan perbankan seperti ini membolehkan beberapa interaksi antara sistem bank dan nasabah. $P C$ banking ini menyediakan pengembangan channel secara tertutup melalui telepon, kadang-kadang disebut home banking. Transaksi dibatasi untuk komunikasi e-mail, transfer uang meninjau saldo rekening, dan melakukan pembayaran tanpa cek

Berdasarkan Office of the Controller of the Currency (OCC) ditemukan beberapa kategori risiko yang ada dalam penyelenggaraan layanan Internet banking, risiko tersebut antara lain, risiko kredit (credit risk), risiko suku bunga (interest rate risk), risiko likuiditas (liquidity risk), risiko transaksi (transaction risk), risiko kepatuhan (compliance risk), dan risiko reputasi (reputation risk) [5]. Risiko kredit adalah risiko terhadap 
pendapatan atau modal yang timbul dari kegagalan obligor untuk menyepakati setiap kontrak dengan bank atau sebaliknya untuk performan yang disetujui. Risiko suku bunga adalah risiko terhadap pendapatan atau modal yang timbul dari pergerakan dalam suku bunga. Evaluasi dari suku bunga harus mempertimbangkan dampak yang kompleks dari produk dan juga dampak dari potensial yang mengubah suku bunga pada pendapatan fee. Risiko likuiditas adalah risiko yang dihadapi oleh bank dalam rangka memenuhi kebutuhan likuiditasnya. Risiko transaksi adalah risiko yang prospektif dan banyak berdampak pada pendapatan dan modal. Hal ini merupakan akibat adanya praktik penipuan, kesalahan, ketidakmampuan dalam penyerahan produk dan jasa, dan memelihara posisi kompetisi dan penawaran jasa serta memperluas produk-produk layanan internet banking. Risiko kepatuhan merupakan risiko yang berdampak terhadap pendapatan dan modal akibat adanya pelanggaran terhadap hukum regulasi atau standar etik. Risiko kepatuhan dapat mengarahkan institusi kepada denda, hukuman uang sipil, pembayaran kerugian/ kerusakan, dan pembatalan kontrak. Risiko kepatuhan juga dapat menyebabkan reputasi berkurang, nilai waralaba (franchise) berkurang, peluang usaha terbatas, potensi ekspansi berkurang, dan ketidakmampuan untuk menjalankan kontrak. Risiko reputasi merupakan sebagian besar dari prospek risiko yang berdampak kepada pendapatan dan modal akibat adanya pendapat negatif dari publik. Hal ini berdampak pada penetapan layanan baru ataupun kelanjutan dari layanan konvensional. Risiko ini membuka persengketaan ke lembaga pengadilan, hilangnya keuangan, dan kemunduran dari nasabahnya.

Memahami critical success factors dalam Internet banking dianggap penting bagi manajemen perbankan dikarenakan berpotensi memerbaiki proses perencanaan strategi instansi perbankan terkait. Rockhart mendefinisikan critical success factors yaitu sejumlah bidang yang terbatas di mana jika terpenuhi secara memuaskan akan dapat menjamin kesuksesan kompetitif bagi organisasi [6]. Dari pengertian ini dapat disimpulkan bahwa critical success factors merupakan poin-poin kunci dalam mencapai misi yang jika dipenuhi akan dapat menjamin kesuksesan kompetitif organisasi.

Dalam penelitian Michelle Bayles tahun 2004 terkait tingkah laku dan kebiasaan nasabah dalam menggunakan layanan internet banking telah dikembangkan sebuah kuesioner yang ditujukan kepada nasabah-nasabah pengguna layanan tersebut [7]. Kuesioner ini meliputi frekuensi aktivitas bertransaksi melalui internet banking yang dinilai dengan menggunakan aktivitas transaksional yang umumnya dilakukan secara online, tatap muka, maupun dengan telepon. Kuesioner ini pun menilai alasan pengguna untuk tidak melakukan aktivitas transaksional secara online serta faktor-faktor yang memengaruhi keputusan awal untuk melakukan perbankan secara online. Bagian terakhir dari kuesioner ini kemudian mengakomodasi peringkat kepentingan dari beberapa rancangan fitur internet banking.

\section{Metodologi}

Mengenal lebih jauh topik internet banking, peneliti mengawali penelitian dengan melakukan pra-analisis melalui wawancara dengan pihak instansi perbankan, yakni senior manager di divisi Teknologi Informasi (TI) yang menangani aplikasi internet banking pada PT. Bank Central Asia, Tbk. Dari praanalisis ini didapatkan perbendaharaan pengetahuan terkait dalam pemfasilitasan layanan internet banking. Langkah berikutnya meliputi pendefinisian rumusan masalah penelitian dan melakukan studi literatur serta kajian penelitian terdahulu. Hasil dari studi literatur merupakan kriteria-kriteria critical success factors yang dipandang penting dari kebutuhan pengguna nasabah individual, yakni meliputi faktor kelengkapan layanan-layanan internet banking dan faktor desain antarmuka website.

Peneliti kemudian menentukan beberapa website internet banking untuk dievaluasi dan dibandingkan kelengkapannya terhadap pendefinisian critical success factors Internet banking. Prosedur evaluasi ini kemudian menghasilkan bukti-bukti implementasi terbaik (best practice) dari masing-masing website studi kasus dalam mendukung pendefinisian critical success factors pada internet banking. Adapun kebutuhan untuk membuktikan sebuah website internet banking telah memenuhi kebutuhan pengguna nasabah individual berdasarkan kriteria critical success factors yang telah didefinisikan pada tahapan sebelumnya. Kemudian disusun instrumen evaluasi website internet banking berupa kuesioner untuk mensurvei nasabah terhadap tiap butiran penilaian website internet banking. Hasil dari kuesioner tersebut akan dianalisis dan dihasilkan CSF internet banking final. Gambar 1 menjelaskan alur metodologi peneltian yang telah dilakukan. 


\section{Hasil dan Pembahasan}

Berdasarkan hasil wawancara pra-analisis, pemfasilitasan layanan internet banking diharapkan dapat meningkatkan tingkat kepercayaan serta kepuasan bertransaksi dan berinteraksi nasabah dalam mengunakan fasilitas internet banking. Berdasarkan perbandingan literatur yang telah dilakukan terkait dimensidimensi layanan transaksi maupun non-transaksi pada internet banking, dapat disimpulkan sebuah rancangan dimensi layanan perbankan yang dapat dilihat pada tabel I.

Sedangkan faktor-faktor yang perlu diperhatikan dalam mendesain sebuah antarmuka website internet banking, dapat disimpulkan sebuah rancangan faktor-faktor desain antarmuka website internet banking yang terdapat pada tabel II.

TABEL I

FAKTOR KESUKSESAN LAYANAN-LAYANAN INTERNET

\begin{tabular}{|c|c|c|}
\hline \multicolumn{3}{|c|}{ BANKING } \\
\hline No. & Jenis Layanan & Layanan-Layanan \\
\hline \multirow[t]{6}{*}{1} & Informasi Rekening & Informasi Saldo \\
\hline & & Mutasi Rekening \\
\hline & & Deposito \\
\hline & & Status Transaksi \\
\hline & & Histori Transaksi \\
\hline & & Daftar Rekening \\
\hline \multirow[t]{9}{*}{2} & Transfer Dana & Transfer Antar Rekening \\
\hline & & Bank Sama \\
\hline & & Transfer Antar Bank \\
\hline & & Domestik Kliring \\
\hline & & Transfer Antar Bank \\
\hline & & Domestik RTGS \\
\hline & & Daftar Rekening Tujuan \\
\hline & & Daftar Transaksi \\
\hline & & Terjadwal \\
\hline \multirow[t]{12}{*}{3} & Pembayaran dan & Kartu Kredit \\
\hline & Pembelian & Telepon \\
\hline & & Seluler/ Handphone \\
\hline & & Internet \\
\hline & & Asuransi \\
\hline & & Angsuran/ Pinjaman/ \\
\hline & & Peronal Loan \\
\hline & & Pajak \\
\hline & & Listrik/ PLN \\
\hline & & Air/ PAM \\
\hline & & Biaya Pendidikan \\
\hline & & Tiket Penerbangan \\
\hline
\end{tabular}

\begin{tabular}{|c|c|c|}
\hline & & $\begin{array}{l}\text { Kereta Api } \\
\text { Tour \& Travel } \\
\text { ZIS dan Qurban } \\
\text { TV Berlangganan } \\
\text { Multi Payment } \\
\text { Autodebit } \\
\text { Voucher Prabayar } \\
\text { Saham } \\
\text { Tiket } \\
\end{array}$ \\
\hline 4 & $\begin{array}{l}\text { Informasi dan Operasi } \\
\text { Pinjaman dan Kredit }\end{array}$ & $\begin{array}{l}\text { Informasi Saldo Kredit } \\
\text { Informasi Transaksi } \\
\text { Kredit } \\
\text { Informasi Tagihan Kartu } \\
\text { Kredit } \\
\text { Informasi Pinjaman } \\
\text { Histori Pembayaran } \\
\text { Pinjaman } \\
\text { Pembayaran Kartu Kredit } \\
\text { Pembayaran Angsuran/ } \\
\text { Pinjaman/ Personal Loan } \\
\text { Simulasi Kredit } \\
\text { Pengajuan Kredit } \\
\end{array}$ \\
\hline 5 & $\begin{array}{l}\text { Download Informasi } \\
\text { Rekening }\end{array}$ & $\begin{array}{l}\text { Informasi Saldo } \\
\text { Mutasi Rekening } \\
\text { Download Reciept } \\
\text { Transaksi }\end{array}$ \\
\hline 6 & Fitur Customer Service & $\begin{array}{l}\text { Call Center } \\
\text { Kotak Pesan/ E-Mail }\end{array}$ \\
\hline 7 & Personalisasi & $\begin{array}{l}\text { Transaksi Favorit } \\
\text { Salam } \\
\text { Bahasa } \\
\text { Administrasi } \\
\end{array}$ \\
\hline 8 & Produk Lain & $\begin{array}{l}\text { Informasi Produk } \\
\text { Investasi } \\
\text { Informasi Kurs } \\
\text { Informasi Suku Bunga } \\
\text { Penempatan Deposito } \\
\text { Berjangka } \\
\text { Status Cek } \\
\text { Layanan Notifikasi SMS } \\
\text { No. Kupon Gebyar } \\
\text { Tahapan BCA (produk } \\
\text { spesifik BCA) } \\
\text { Poin Rejeki BNI Taplus } \\
\text { (produk spesifik BNI) }\end{array}$ \\
\hline
\end{tabular}

Saham

Informasi Transaksi

Informasi Tagihan Kartı

Pinjaman

Pembayaran Kartu Kredi

Simulasi Kredit

load Reciep

Administrasi

Investasi

Informasi Kurs

nformasi Suku Bunga

Berjangka

Status Cek

Layanan Notifikasi SMS

No. Kupon Gebya

spesifik BCA)

(produk spesifik BNI) 


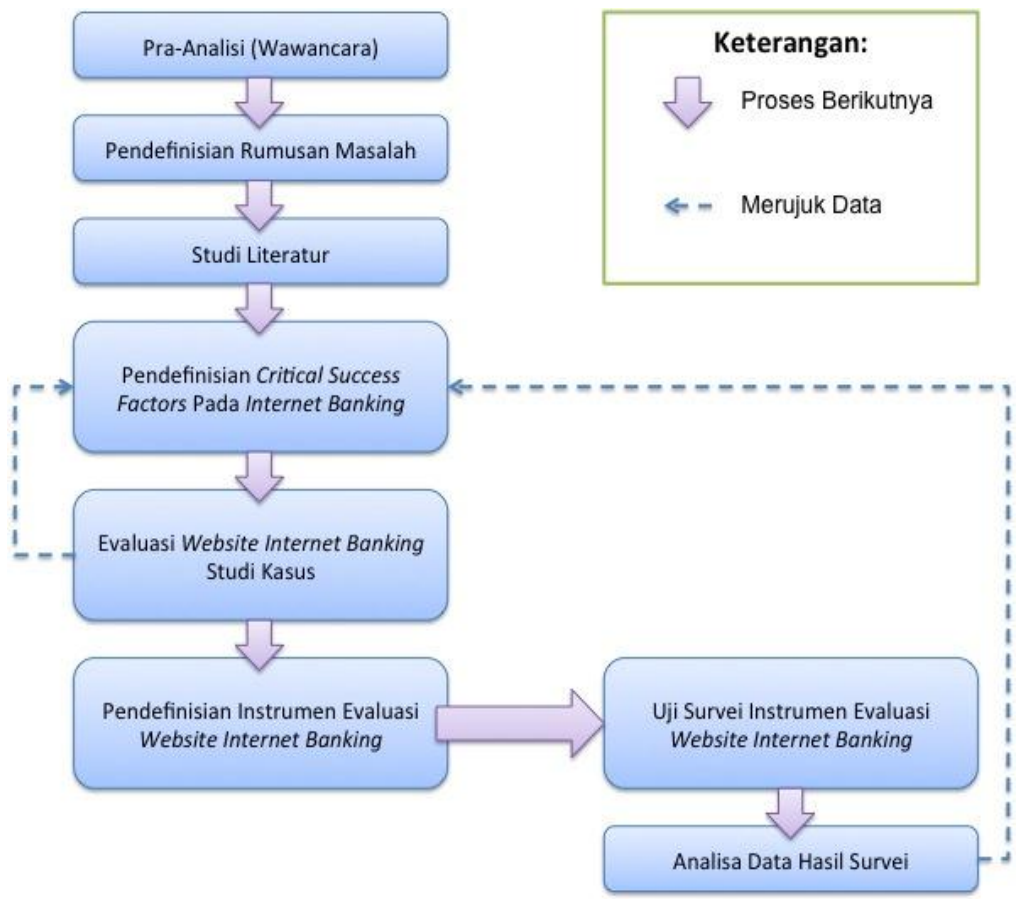

Gambar 1. Alur metodologi penelitian.

TABEL II

FAKTOR DESAIN ANTARMUKA WEBSITE INTERNET BANKING

\begin{tabular}{|c|c|c|}
\hline No. & Faktor Desain Antarmuka & Butiran Desain \\
\hline 1 & Membuat Pengguna Merasa Aman & $\begin{array}{l}\text { Pergunakan gambar profesional pada website. } \\
\text { Tunjukkan halaman-halaman dengan enkripsi. } \\
\text { Misal logo "CyberTrust Secured Website" (klikBCA) } \\
\text { Cantumkan layanan call center yang dapat dihubungi. } \\
\text { Sertakan privacy policy pada website. }\end{array}$ \\
\hline 2 & Navigasi Mudah & $\begin{array}{l}\text { Pergunakan konvensi icon yang standar. } \\
\text { Misal icon floppy disk menandakan 'save' (BNI Internet banking) } \\
\text { Hindari penggunaan link yang tidak relevan. } \\
\text { Perlihatkan struktur halaman website. } \\
\text { Misal struktur website ditunjukan dengan navigation toolbar } \\
\text { (klikBCA) } \\
\text { Jika navigation toolbars tidak memadai, pergunakan breadcrumb } \\
\text { links. } \\
\text { Hindari penempatan halaman yang menuntut lebih dari tiga klik dari } \\
\text { halaman lain untuk mencapainya. Misal dengan bantuan site map } \\
\text { (klikBCA) } \\
\text { Ketersediaan alternatif bantuan navigasi. Misal search tool (Mandiri } \\
\text { Internet) }\end{array}$ \\
\hline 3 & Visibilitas Status Sistem & $\begin{array}{l}\text { Berikan feedback yang artikulatoris yakni umpan balik yang } \\
\text { mengkonfirmasikan pengoperasian fisik yang baru saja pengguna } \\
\text { lakukan. } \\
\text { Misal memunculkan kata yang diketikan melalui keyboard } \\
\text { (klikBCA) ataupun membunyikan suara 'beep' dari sistem sebagai } \\
\text { notifikasi } \\
\text { Berikan feedback yang sesuai semantik yakni umpan balik yang } \\
\text { menegaskan maksud dari suatu tindakan. Misal isian yang dipilih } \\
\text { ditandai dengan highlight biru (klikBCA) } \\
\text { Berikan indikator status yang tepat untuk menunjukkan kemajuan } \\
\text { sebuah operasi panjang kepada pengguna. } \\
\text { Mungkinkan pengguna untuk segera mengetahui apakah isiannya } \\
\text { benar atau salah. } \\
\text { Misal field 'Password strength' memonitor tiap character yang } \\
\text { dimasukan pada field 'Type new password' (Windows Live) }\end{array}$ \\
\hline 4 & Feedback Mudah Dipahami & $\begin{array}{l}\text { Sistem harus berkomunikasi dengan bahasa pengguna yakni dengan } \\
\text { kata-kata, frase dan konsep yang dikenal oleh pengguna, seperti } \\
\text { 'inbox'. } \\
\text { Hindari pesan-pesan ambigu, seperti 'Hit any key to continue'. } \\
\text { Hindari menggunakan pesan yang mengancam atau }\end{array}$ \\
\hline
\end{tabular}




\begin{tabular}{|c|c|c|}
\hline & & $\begin{array}{l}\text { mengkhawatirkan, seperti 'Fatal error'. } \\
\text { Gunakan kata-kata yang spesifik dan konstruktif pada pesan error, } \\
\text { seperti 'Please re-enter your name'. } \\
\text { Pada beberapa kasus, buatlah sehingga sistem adalah yang } \\
\text { disalahkan untuk sebuah error, seperti 'Unrecognized command' } \\
\text { dibandingkan 'Illegal command'. }\end{array}$ \\
\hline 5 & Kemudahan Mengontrol Aktivitas & $\begin{array}{l}\text { Buatlah sehingga tindakan pengguna dengan mudah dapat } \\
\text { dikembalikan ke kondisi sebelumnya, seperti dengan 'Undo'. } \\
\text { Mungkinkan rute keluar dari sebuah operasi. Misal tombol 'Batal' } \\
\text { pada transaksi (klikBCA) }\end{array}$ \\
\hline 6 & Konsistensi dan Standardisasi & $\begin{array}{l}\text { Terminologi harus konsisten antar tampilan. } \\
\text { Icon harus konsisten antara tampilan. } \\
\text { Penggunaan warna harus konsisten antara tampilan yang memiliki } \\
\text { fungsi serupa. }\end{array}$ \\
\hline 7 & Pencegahan dan Penanganan Error & $\begin{array}{l}\text { Pada pengisian data formulir, sertakan pesan pemberitahuan } \\
\text { informasi cara pengisian data yang benar. Misal memberikan } \\
\text { catatan kaki mengenai pengisian sebuah field (klikBCA) } \\
\text { Sertakan penanda pada bagian pengisian data yang salah, disertai } \\
\text { dengan solusi terbaik dalam mengisi data tersebut. Misal } \\
\text { meletakkan penanda kesalahan dan solusi pada daerah field yang } \\
\text { error (klikBCA) }\end{array}$ \\
\hline 8 & $\begin{array}{lll}\text { Memudahkan } & \text { Mengenal dibandingkan } \\
\text { Mengingat } & & \end{array}$ & $\begin{array}{l}\text { Organisir informasi dan pengisian data menjadi bagian-bagian kecil. } \\
\text { Misal Informasi terpecahkan menjadi bagian-bagian kecil pada } \\
\text { pengisian form (BNI Internet banking) } \\
\text { Mudahkan pengguna untuk melihat instruksi, peringatan, dan } \\
\text { feedback dari suatu layanan. } \\
\text { Misal penempatan bantuan kontekstual pada daerah kotak isian } \\
\text { (klikBCA) } \\
\text { Rancang menu yang mudah dipantau secara keseluruhan sehingga } \\
\text { memberikan rekognisi menu layanan yang pengguna butuhkan } \\
\text { diantara keseluruhan menu layanan yang tersedia. Misal } \\
\text { penempatkan bantuan kontekstual pada daerah kotak isian } \\
\text { (klikBCA) }\end{array}$ \\
\hline 9 & $\begin{array}{l}\text { Fleksibilitas, Efisiensi, serta Kontrol dari } \\
\text { Penggunaan }\end{array}$ & $\begin{array}{l}\text { Gunakan elemen akselerator untuk tindakan yang sering dilakukan } \\
\text { pengguna, tanpa harus memperunjukannya kepada pengguna awam } \\
\text { dengan tujuan mempercepat interaksi bagi pengguna yang telah } \\
\text { fasih, seperti dengan keyboard shortcuts. } \\
\text { Fasilitasi pengguna untuk menyesuaikan aspek tampilan mereka } \\
\text { agar sesuai preferensi pribadi, seperti dengan menu shortcuts. } \\
\text { Misal memiliki menu shortcut terhadap 'Transaksi Favorit' } \\
\text { (Mandiri Internet) }\end{array}$ \\
\hline 10 & Estetika dan Desain Minimalis & $\begin{array}{l}\text { Jangan terlalu meramaikan tampilan dengan informasi yang tidak } \\
\text { diperlukan. } \\
\text { Informasi tekstual harus terstruktur dengan memecahnya menjadi } \\
\text { potongan-potongan terpisah yang bermakna untuk membantu } \\
\text { pengguna memindai dan menemukan informasi yang dicarinya. }\end{array}$ \\
\hline 11 & Bantuan dan Dokumentasi & $\begin{array}{l}\text { Bantuan kontekstual yang jelas dan mudah dinavigasi. } \\
\text { Embedded video dapat digunakan untuk mengunjukkan fitur-fitur } \\
\text { serta membantu pengguna dalam mulai menggunakan produk yang } \\
\text { ditawarkan. } \\
\text { Bantuan berupa instruksi atau petunjuk yang ditampilkan saat } \\
\text { melayangkan (hover) cursor diatas sebuah objek untuk menjawab } \\
\text { pertanyaan-pertanyaan yang kerap dipertanyakan pada sebuah field. } \\
\text { Halaman 'Help' dengan kumpulan resource bantuan, seperti search, } \\
\text { FAQ, video tutorials, customer forums. }\end{array}$ \\
\hline
\end{tabular}

Berdasarkan pendefinisian CSF awal pada tabel I dan tabel II, langkah selanjutnya adalah membuat kuesioner dan menyebarkan instrumen evaluasi dengan snowball sampling yang digunakan untukmengidentifikasi subjek (responden) berpotensi untuk dilibatkan dalam penelitian yang subjeknya sulit untuk ditemukan [8]. Berdasarkan uji instrumen evaluasi pada sampel populasi civitas Fakultas Ilmu Komputer, Universitas Indonesia terhadap website studi kasus menunjukkan rata-rata penilaian puas (nilai mean 2.37) pada faktor layanan-layanan Internet banking dan rata-rata nilai agak puas (nilai mean 2.57) pada faktor desain antarmuka website Internet banking.

\section{Kesimpulan}

Faktor kesuksesan layanan-layanan Internet banking meliputi dimensi-dimensi layanan perbankan yaitu informasi rekening, transfer dana, pembayaran dan pembelian, informasi dan operasi pinjaman dan kredit, download informasi rekening, fitur customer service, personalisasi 
serta produk lain. Sedangkan faktor desain antarmuka website internet banking meliputi dimensi-dimensi butiran desain yaitu membuat pengguna merasa aman, navigasi mudah, visibilitas status sistem, feedback mudah dipahami, kemudahan mengontrol aktivitas, konsistensi dan standardisasi, pencegahan dan penanganan error, memudahkan mengenal dibandingkan mengingat, fleksibilitas, efisiensi, serta kontrol dari penggunaan, estetika dan desain minimalis, bantuan dan dokumentasi. Berdasarkan evaluasi website internet banking, implementasi dimensi-dimensi critical success factors kelengkapan layanan-layanan internet banking dan desain antarmuka website telah dengan baik diimplementasikan pada masing-masing website studi kasus BCA, Bank Mandiri, dan BNI. Jenis nasabah, baik dipandang dari segi pendidikan, profesi, maupun pengalaman sebagai pengguna layanan internet banking, memiliki karakteristik tersendiri dalam melakukan transaksi perbankan. Dengan demikian analisis data survei responden perlu mempertimbangkan karakteristikkarakteristik tersebut dalam mengambil konklusi penelitian.

Untuk kelanjutan penelitian ini kedepannya, evaluasi website internet banking hendaknya melibatkan studi kasus dengan berbagai preferensi status bank, antara lain beberapa sampel studi kasus bank terbaik dan bank yang belum maju. Hal ini bermaksud agar dapat memberikan hasil penelitian yang lebih konkret. Selain itu, pada pengembangan penelitian selanjutnya terkait critical success factors pada website internet banking hendaknya melibatkan pembahasan faktor Service Level (seperti performance dan downtime) dan faktor Security dari website internet banking. Disamping itu, untuk penelitian berikutnya akan lebih baik hasilnya jika melibatkan pembahasan pengembangan lebih lanjut (future development) yang dapat diimplementasikan pada layanan internet banking ini.

\section{Referensi}

[1] S.C. Chan \& T.M. Lu, "Understanding Internet Banking Adoption and Use Behaviour: A Hong Kong Perspective," Journal of Global Information Management, vol. 12, pp. 21-43, 2004.

[2] D. Hamdani, S. Indra, \& R. Panggabean, Internet Banking Paling Sukses di Dunia?, Gatra, http://www.gatra.com/2001-0701/artikel.php?id=7403, Jun. 23，2001, retrieved November 14, 2010

[3] B. Rahardjo, Aspek Teknologi dan Keamanan dalam Internet Banking, PT INDOCISC,

http://www.cert.or.id/ budi/articles/internetbanking-bi-1.pdf, Aug. 16, 2001, retrieved November 14, 2010.

[4] A.R. Noor, Bank Permata Raup Rp 3 M dari e-banking, Detik,

http://m.detik.com/read/2005/11/22/122034/ 483737/417/bank-permata-raup-rp-3-m-darie-banking, November 22, 2005, retrieved November 13, 2010.

[5] B.A. Riswandi, Aspek Hukum Internet Banking. Raja Grafindo Persada, Jakarta, 2005.

[6] J.F. Rockhart, "Chief Executives Define Their Own Data Needs," Harvard Business Review, vol. 57 (2), pp. 81-93, 1979.

[7] M. Bayles, Online Banking: Why People Are Branching Out, Software Usabilty Research Laboratory, http://www.surl.org/usabilitynews/62/online _banking.asp, 2004, retrieved May 14, 2010.

[8] J.J. Castillo, Snowball Sampling, Experiment-Resources. http://www.experimentresources.com/snowball-sampling.html, 2009, retrieved November 13, 2010. 